Christian Bjørnskov

Social trust and the growth of schooling

Department of Economics 


\title{
Social trust and the growth of schooling
}

\author{
Christian Bjørnskov*
}

\begin{abstract}
:
The paper develops a simple model to exemplify how social trust might affect the growth of schooling through lowering transaction costs associated with employing educated individuals. In a sample of 52 countries, the paper thereafter provides empirical evidence that trust has led to faster growth of schooling in the period 19602000. The findings are robust to the inclusion of a set of control variables and being estimated using an instrumental variables approach.
\end{abstract}

Keywords: Trust, Schooling, Economic development JEL Codes: J24, O15, Z13

\footnotetext{
* Aarhus School of Business, University of Aarhus, Department of Economics, Prismet, Silkeborgvej 2, DK-8000 Aarhus C, Denmark, Phone: +45 894861 81; Fax: +45 894861 97; E-mail: ChBj@asb.dk. I am grateful to Tor Eriksson, Maurizio Franzini, participants at workshops in Aarhus and Rome, and an anonymous referee for suggestions that improved the paper. Any remaining errors are entirely my responsibility.
} 


\section{Introduction}

Sir Edward Coke remarked as early as the $16^{\text {th }}$ century that 'there is no jewel in the world comparable to learning'. This jewel has in recent decades grown and been extended to many more people as the post-war period has witnessed an impressive improvement of schooling in much of the world. Average schooling rates of people in Western Europe and North America have increased dramatically and even more impressive increases have happened in the Asian tiger economies. This accumulation of education has had advantageous effects, first and foremost by leading to faster economic development as proposed by the endogenous growth literature (Barro, 1997; Topel, 1999; Bassanini and Scarpetta, 2002). In addition, schooling is often considered an indispensable component of social and human development, as e.g. in the United Nations’ Human Development Index (UNDP, 2003). Hence, the importance of accumulating education, one would think, would create a demand for and interest in research in the reasons for such differences, yet the literature has not received the same attention as that of growth (see Hanushek, 1986; Hanushek and Luque, 2003).

In addition to the standard argument that countries in various ways invest in the broad extension and quality of education, the explanation seems to be that countries with low schooling rates catch up, i.e. achieve faster growth of schooling. However, two supplementary explanations are offered by the recent surge in research on the concept of social capital, which is usually defined as 'features of social organization, such as trust, norms, and networks that can improve the efficiency of society by facilitating coordinated actions’ (Putnam, 1993, p. 167). Putnam argued that social trust - itself defined by Fukuyama (1995, p. 153) as arising when 'a community shares a set of moral values in such a way as to create regular expectations of regular and honest behavior' - 
is created through repeated interactions in voluntary organizations. In other words, individuals learn to trust each other by meeting and interacting on a voluntary basis, for example in schools. Yet, subsequent studies have questioned this mechanism. Knack and Keefer (1997) note that the correlation between trust and network measures in a country sample disappears when controlling for education while Uslaner (2002) finds neither empirical evidence of this association nor proper theoretical arguments why particularized trust emerging in face-to-face interactions should carry over into trust towards strangers. In addition, recent studies find that trust and networks have substantially differing consequences. For example, Zak and Knack (2001) and Beugelsdijk, de Groot \& van Schaik (2004) find that trust is robustly related to growth while Knack (2003) finds only mixed support for Putnam's notion that voluntary organizational activity affects growth and Bjornskov (2006) shows that the association between social capital and governance is entirely due to trust. There is thus mounting evidence suggesting that social capital consists of diverse elements while virtually all studies find some association between one or more of these elements and education.

The original work on social capital by James Coleman (1988) indeed focused exclusively on its connection to educational outcomes. ${ }^{1}$ Entitled 'Social capital in the creation of human capital', the study argued that communities rich in trust and social connections achieve low rates of high school drop outs. Coleman suggested that this association between social and human capital was first and foremost an effect of family social capital, i.e. that children in families with strong bonds between children and

\footnotetext{
${ }^{1}$ Strictly speaking, Coleman was not the first to employ a social capital concept. The work of Bourdieu (1986) is an example of a Marxian-inspired approach that differs markedly from the current social capital paradigm while earlier contributions of e.g. Jacobs (1961) and Loury (1977) hardly can be said to have had an impact comparable to that of Coleman's work.
} 
adults have easy access to adults' human capital (see also Teachman, Paasch \& Carver, 1997). Children in such environments would therefore be more likely to succeed in education. Coleman, however, also touched upon social capital outside the family in the form of children's access to the human capital of non-kin adults and found evidence of effects arising from both types of social capital on the likelihood of dropping out of high school. Social capital in this form thus has public goods aspects that are only accessible in communities where people trust that others will return favours such as helping their children. More recently, Putnam (2000, p. 301) therefore finds reason to stress the overriding importance of trust in a sample of American communities, noting that 'even communities with many material and cultural advantages do a poor job of educating their kids if the adults in those communities don't connect with one another'. These findings extend to cross-country comparisons where la Porta, Lopez-de-Silanes, Schleifer \& Vishny (1997) likewise find that the effect of trust on schooling outcomes is quite strong, showing that a one-standard deviation increase in social trust raises the percentage of a population graduating from high school by about one half of a standard deviation.

Conversely, a number of other studies have argued for the reverse causality. The work by Knack and Keefer (1997) notes the correlation between levels of social trust and schooling and interprets it as an effect going from human to social capital. Such effects are intuitively easy to interpret as noted by the authors. Higher learning implies that individuals become better informed and better at interpreting perceived information, as well as becoming more conscious of the consequences of actions taken by themselves and others. Furthermore, schooling has a socialization effect, which along the lines of Putnam could induce individuals to trust and engage in voluntary 
organizational activity. Alternatively, Gradstein and Justman (2000) model the process as one in which social cohesion reduces rent seeking, which strengthens incentives for investments in human capital. Social cohesion, in turn, is affected by investments in public education that this way comes to affect the accumulation of social capital. In addition, Zak and Knack (2001) also note that trust may proxy for subjective time preference rates, which would influence decisions regarding investments in education. A number of other studies relying on simple OLS estimates have found similar effects of schooling (e.g. Schneider, Teske, Marschall, Mintrom \& Roch, 1997; Knack and Zak, 2002; Berggren and Jordahl, 2006).

These alternatives are not necessarily strict substitutes, but for policy purposes, it may be necessary to know the relative strength of each causal direction, as policy implications differ in the two extremes. If trust causes schooling growth, and not vice versa, the simple implication is that investments in education may be cheaper in hightrust societies. Moreover, this connection might explain part of the growth effect documented by recent studies (e.g. Zak and Knack, 2001; Beugelsdijk et al., 2004). In the other extreme where schooling causes trust, investing in education is equally expensive in all countries, all other things being equal, yet have the additional external effect of raising trust levels. In the first case, returns to investments in education may be equal but costs are lower in high-trust countries, while the latter case would imply that low-trust countries have higher returns to such investments, given that there are decreasing returns to social trust. The causal links are therefore of immediate policy relevance as well as being an unresolved research question. The main finding of this paper - that social trust exerts a robust and causal influence on the growth rate of 
schooling - therefore contradicts previous literature suggesting that education is a determinant of trust and also leads to different policy implications.

The rest of the paper is structured as follows. Section 2 presents a theoretical link between social trust and the growth of schooling. Section 3 describes the data while Section 4 uses them to test the theoretical explanations in a set of cross-country regressions. Section 5 concludes and draws some implications of the findings.

2. An alternative link between social trust and schooling

Two different views on the connection between social and human capital have been introduced by previous literature. An alternative third explanation of why social trust could lead to improved schooling builds on the potential effects of trust on search costs in labour markets. While it posits a causal relation going from social trust to schooling, it differs from the Coleman explanation in focussing on the demand for education where previous research has focussed on the supply. In short, the argument is that when interpersonal trust and honesty is low in society, employers will be highly exposed to hiring employees who lack the social skills needed to cooperate efficiently and thereby reap the full gains of their human capital. Employers will therefore tend to put relatively more emphasis on direct information obtained from trustworthy sources on job applicants’ social skills and relatively less emphasis on formal qualifications such as education, as a way of hedging the risk of getting a 'bad' employee. This reaction comes about as employers may not be able to monitor educated workers without considerable cost due to the complexity of their work tasks. Such rational reactions to poor general quality of information benefits the employer but has the 
external effect that it tends to increase the transaction costs associated with employing educated labour, thereby lowering the general level of education in society.

However, this paper does not focus on levels but the on improvements of schooling during the last four decades. With respect to the theoretical explanations above, it is worth noting that only one of the three may entail a real association between social trust and the growth of schooling. Knack and Keefer's (1997) notion that human capital spurs the development of social capital suffers from an inability to explain the apparent persistence of social trust as well as specific outcomes related to trust. For example, if schooling growth led to increasing trust levels, one would also expect to see corruption levels converge over time, which is not the conclusion of most studies. In addition, trust levels as measured by the World Values Surveys since 1981 seem to be rather stable across time despite the substantial improvements in schooling (Uslaner, 2002; Volken, 2002). Likewise, Coleman’s (1988) account of the association would imply a weak link between social capital and human capital growth, as rapidly increasing levels of education would render the education of adults potentially obsolete. Conversely, the alternative search costs view proposed here also implies that as the demand for formal skills increases - as has certainly been the case with the post-war period move towards knowledge-intensive production - high-trust societies will experience faster accumulation of education, all other things being equal, as firms' costs of hiring educated employees are lower in such societies. This mechanism can be formalized in the following simple way.

The model consists of an economy with many identical firms and workers who share their time between work and education. Assume that uneducated individuals receive the wage $w_{0}$ (which acts as a numeraire in the model) while educated individuals 
receive a wage $w_{l}$ that depends on the level of their education, $l$. In the long run, the level of education naturally reacts to the wage, as individuals can observe the demand of education from firms' behaviour. The response of education to wages, $d l / d w_{l}$, thus represents a supply side effect, which firms take into account, and optimal supply of education is therefore determined within the model. Since firms use both educated and uneducated workers, they have two options. Firms can choose to employ uneducated individuals on whom they have good information, for example only hiring those whom they personally know to be 'willing' to work. These workers can furthermore be monitored easily and at relatively low cost, given their typical work tasks. Alternatively, firms can employ individuals with education, which involves risk, as not all individuals are trustworthy in the sense that they can be expected to do their job efficiently. This choice is more costly, as the performance of educated workers is likely to be substantially more difficult and costly to measure given the higher complexity of their work tasks. The model therefore posits two types of educated workers, differing with respect to their trustworthiness, and different monitoring costs between uneducated and educated workers. For simplicity, it is assumed that uneducated workers can be monitored at negligible cost while the costs of monitoring educated workers are prohibitive in a specific sense outlined below. ${ }^{2}$

\footnotetext{
${ }^{2}$ The standard theoretical solution in principal-agent models is monitoring (see e.g. Milgrom and Roberts, 1992). Building in this option in the model would nevertheless only complicate it without altering the qualitative implications. It should furthermore be stressed that there need not be a systematic difference between the trustworthiness of educated and uneducated individuals. Given the costs of monitoring and obtaining information, trustworthiness simply becomes more important when employing educated workers as uneducated workers are easily monitored.
} 
With trustworthiness comes a set of social skills such as an ability to cooperate, as this type typically reciprocates favours and acts according to society’s fairness norms (e.g. Glaeser, Laibson, Scheinkman \& Soutter, 2000; Uslaner, 2002; Guerra and Zizzo, 2004). The untrustworthy type is less likely to reciprocate and respond to trust, which makes cooperation more difficult and lowers labour productivity. ${ }^{3}$ As such, assume that each trustworthy educated individual produces $b l^{\alpha}$ units of the output where $\alpha>0$ and $b>1$ measures the technological sophistication of production. Untrustworthy individuals are less productive, producing the fraction $\sigma<1$ of that of trustworthy educated individuals, while uneducated individuals produce 1 unit in what can be thought of as a complementary production facility. As trustworthiness is unobservable, firms employing educated employees thus experience an adverse selection problem that provides a further incentive to acquire information on the trustworthiness of potential employees.

Total production $y$ of a representative firm in any period is given by equation 1 , which is a slightly modified Cobb-Douglas production function, where $m$ and $n$ are the shares of employees with and without education, respectively (time subscripts are dropped for simplicity). Firms maximize the present value of profits $\pi$ in equation 2 where $c$ is the cost of ascertaining the trustworthiness of any individual and $\theta$ is the

\footnotetext{
${ }^{3}$ The question of whether trust and trustworthiness improves productivity is explored by Knack and Keefer (1997) who found that trust is strongly associated with labour productivity. Related research also suggests that high-trust countries might have higher total factor productivity (TFP), all other things being equal. Becker and Murphy (1992) suggest that coordination between different tasks might well be defined by non-economic considerations while Grafton, Knowles and Owen (2002) find significant relations between TFP, labour productivity and various measures of social divergence that are strongly related to social trust.
} 
share of all workers that are screened for their social skills. For this purpose, the model assumes the existence of a technology or institution that at a fixed price can reveal the trustworthiness of agents and supply a trustworthy agent, and the term $\theta m c$ thus represents a transaction cost associated with hiring new employees. As in Zak and Knack (2001), the model focuses on the starkest case, the one-shot transaction without individual-specific information. The notion that firms can reveal such characteristics of employees only at a cost is related to the similar theoretical role of investment brokers in Zak and Knack (2001). The sense in which monitoring of educated workers is prohibitively costly can now be clarified: the profit loss from employing untrustworthy educated workers that are less productive (by $\sigma$ ), plus the costs of revealing their trustworthiness $(c)$ borne by firms must not exceed the potential monitoring costs for screening to be the optimal solution to adverse selection. A further implicit assumption is thus that trustworthy workers are not able to send signals of trustworthiness that cannot be easily imitated by untrustworthy individuals; i.e. such signals are reduced to pure cheap talk.

The parameter $\omega$ in equation 3 is the probability that an educated individual selected at random is trustworthy and therefore becomes the social trust parameter of the model by capturing the trust employers in general have in their fellow citizens. Average trustworthiness $\varphi$ of educated employees is hence determined by the distribution of the two types within the firm. Finally, $i$ is an investment in new labouraugmenting technology that raises the value of the $b$-parameter and hence the content of education in production. Consequently, equation 4 is the equation of motion for technology where $b_{-1}$ is technology lagged one period and $\mu$ defines the effectiveness of investments. 


$$
\begin{aligned}
& y=\left[m b l^{\alpha}(\varphi+(1-\varphi) \sigma)\right]^{\beta} n^{\delta} \\
& \pi=y-w_{1} m-w_{0} n-\theta m c-i \\
& \varphi=\omega+(1-\omega) \theta \\
& b=b_{-1}+\mu i
\end{aligned}
$$

Assume for simplicity that the relation between $m$ and $n$ need not be the same within firms as in society as a whole. Any public and service sectors thus serve only two purposes in the long run: they swallow any potential unemployment and satisfy firms’ demand for education so as to equate $m$ with the actual share of the population holding an education. ${ }^{4}$ With an interest rate $r$, solving infinitely-lived firms' profit maximization problem with respect to $m, n, w_{1}, \theta$ and $i$ yields a set of first order conditions that determine e.g. the wage paid to educated workers. Imposing the assumption that the economy is characterized by imperfect competition in the sense that all firms take a mark-up of $\gamma$ and combining this with the system above yields the steady state level of schooling in the appendix. From this follows a set of implications including a unique balanced growth path and investment level as well as a growth path of schooling in equation 8. The temporal properties of schooling with respect to social trust as set out in equation 9 comprise the main focus of the remainder of the paper. Note that $\hat{y}$ denotes the growth rate of $y$, i.e. changes in $y$ over $y$; the same notation is used for $l$.

\footnotetext{
${ }^{4}$ See the appendix for a relaxation of this assumption.
} 


$$
\begin{aligned}
& y=\frac{(1+r)}{\mu \beta} b \\
& i^{*}=(1-\beta-\delta-\gamma) y \\
& \hat{y}=\frac{(1+r)}{\mu \beta}(1-\beta-\delta-\gamma) \\
& \hat{l}=\frac{1}{\alpha}\left[\frac{1}{b}-\frac{2(1-\omega)(1-\sigma)}{\delta} y\right] i^{*} \\
& \frac{d \hat{l}}{d \omega}=\frac{2 y(1-\sigma)}{\alpha \delta} i^{*}
\end{aligned}
$$

The set of equations above has four main implications: i) that income is proportional to the level of technology in production, i.e. that income growth depends on investments in technology; ii) that the investment ratio $i / y$ is constant and dependent on market structure; iii) that schooling levels converge, due to the Solow-type assumptions of the model; and iv) that the resulting growth of schooling depends positively on the level of trust, $\omega .{ }^{5}$ This last implication arises from the effect of social trust on the transaction costs associated with revealing the trustworthiness of potential employees, an effect related to the approach in Zak and Knack (2001). As usual, the theoretical model only shows the implications of a possible transmission channel. While

\footnotetext{
${ }^{5}$ It should be noted that even though the model has the appearance of a closed economy, the degree of monopolistic competition captured by the mark-up $\gamma$ is likely to decrease with increasing openness to foreign competition. The investment rate in equation 6 as well as the steady state growth rate in equation 7 can therefore be argued to depend positively on openness as is standard (e.g. Levine and Renelt, 1992; Wazciarg, 2001). Note also that at very low levels of trust steady state growth of schooling may be negative, i.e. eventually resulting in a poverty trap similar to that found in Zak and Knack (2001); see the appendix for further discussion.
} 
the validity of this specific assumption can only be ascertained in individual- or firmlevel studies, it is the implication at the macro-level that is tested in the following.

\section{Data}

The aim of the following section is to establish whether the latter implication holds when confronted with data. The data for estimating the relation between the growth of schooling and social trust are drawn from various sources; see appendix Table A1 for sources and Table A2 for descriptive statistics. The variables of particular interest are four measures of schooling and a measure of social trust. Firstly, the average length of schooling for adults over 25 years of age and the same measure for females are used to capture effects on total education. Secondly, the percentage of the population with a secondary education is employed as a first measure of higher education since mandatory primary schooling requirements in some countries may potentially obfuscate the effect of trust. Thirdly, the percentage of the population with a tertiary education, i.e. college undergraduate degrees and higher, is entered. As such, it should be possible to ascertain the effects of trust on various degrees of education. ${ }^{6}$

As the preferred measure of social trust, the generalized trust scores from the World Values Survey project are employed. The measure is the average of all available observations for each country from three waves of the survey conducted in 1981, 1990-

\footnotetext{
${ }^{6}$ A potential reason for not being able to distinguish between the four indicators is that education measures are often highly correlated. In the present sample, the correlation between the growth rates of average total schooling and average female schooling is 0.93 while the correlation between the former and the growth of secondary education is 0.76 and none of the measures are significantly associated with tertiary education. Hence, an alternative interpretation of the use of different indicators is to see it as a robustness test of a general claim.
} 
93, and either 1995-97 or 1999-2000; the appendix reports the trust scores for all countries included. Previous research has shown that this is a well-functioning measure of average trustworthiness and honesty, which is remarkably stable over time (Uslaner, 2002; Volken, 2002), although some authors question its validity. Fine (2001, p. 105), referring to the concept of social capital in which trust is an important component, for example considers that given that it 'is context-dependent - and context is highly variable by how, when and whom, then any conclusion [reached by empirical studies] are themselves illegitimate as the basis for generalisation to other circumstances’. Nevertheless, Knack (2001) reports the results of an experiment in which a number of wallets were dropped in cities around the world, a test that may be particularly suited to reveal people's trustworthiness as returning a wallet is an entirely private decision, being unobservable by the legal system. Contrary to Fine’s conjecture, the national trust scores turn out to be good predictors of how many wallets in each country were returned with the contents intact. Another indication of the validity of this measure is that social trust is a robust cross-country determinant of aggregate behavioral features such as corruption or the prevalence of violent crime (Lederman, Loayza \& Menéndez, 2002; Uslaner, 2002). National scores of social trust hence seem to measure the extent to which people in a country can in general be expected to 'do the right thing' in a variety of contexts.

Glaeser et al. (2000) and Carpenter (2002) moreover note that in experiments, individual trust scores appear to be a reasonably good measure of respondents' own trustworthiness and hence whether respondents themselves can be expected to do the 
right thing. ${ }^{7}$ However, even at the individual level it is difficult to separate trust and trustworthiness. Deutsch (1958, p. 268) defined trustworthiness as implying 'that the trustworthy person is aware of being trusted and that he is somehow bound by the trust which is invested in him' and found that trust and trustworthiness were strongly related in experimental behavior. Experimental work on trust responsiveness has also questioned the distinction between trust and trustworthiness by supporting Deutsch's implication, showing that trusters are indeed more likely to reciprocate trust, i.e. to be trustworthy (Dufwenberg and Gneezy, 2000; Guerra and Zizzo, 2004). Likewise, Ahn and Ostrom (2002, p. 21) treat social trust as ‘a baseline expectation of other's trustworthiness [...which] reflects the average level of trustworthiness in society'. Hence, for trust and trustworthiness to differ at the national level, individuals not only have to form systematically wrong expectations of fellow citizens' trustworthiness, but also need to continue to do so. As this seems highly unlikely, the social trust scores are therefore treated as a reflection of both average trust and trustworthiness in the following. As a final point to note, social trust is measured in the last half of the period considered below. However, the national trust scores seem to have been rather stable throughout the period in which the WVS has measured them, indicating that the time of measurement may not be a problem (Uslaner, 2002; Volken, 2002). As such, the

\footnotetext{
${ }^{7}$ The much-quoted work by Glaeser et al. (2000) indicates that social trust does not have any influence on the amount sent by the first mover in ultimatum games. However, it must be stressed that these experiments are not anonymous and that subjects in a number of cases were allowed to choose whom to play with. The results in the Glaeser paper therefore refer to particularized trust instead of generalized or social trust. As such, the finding that measures of trust and trustworthiness are not related in the experiments is likely to be a reflection of the rather weak association between the two types of trust.
} 
variable used in the following may not be ideal but nonetheless provides a relatively reliable and valid proxy for the $\omega$ in the model.

In the next section, GDP per capita and the initial 1960 level of schooling enter as control variables in all regressions while a subset of the analyses also include regional dummies covering Latin America, the post-communist countries, Asia and the Pacific, North Africa and the Middle East, and Sub-Saharan Africa. The section additionally includes a robustness test by extreme bounds analysis (EBA) as introduced by Leamer (1985) and popularized by Levine and Renelt (1992). The pool from which variables are drawn for the EBA includes the initial fertility rate, openness to trade, market distortions, income inequality, democratic tenure, population density, governments' share of the economy, expenditure per student, GDP growth, average intelligence (IQ), and governance; appendix Table A1 lists the definitions and sources and Table A2 gives descriptive statistics. The rationales for entering these variables are as follows. i) High initial fertility could be expected to affect schooling growth negatively as families with many children may tend to invest less in education due to being income or credit constrained. Fertility may also proxy for age structure as high fertility means a large share of young people, which Berggren and Jordahl (2006) find to be negatively associated with social trust. ii) Increased international competition could create demand for skilled labour and investments in education as a way of increasing competitiveness, which would imply a positive association between the growth of schooling and openness to trade, captured by either openness or a direct measure of market distortions deriving from Forbes (2000) that is related to the degree of integration in the world market. iii) Income inequality could lead to lower investments in education, as particularly poor people may not invest as much due to credit constraints (e.g. Perotti, 
1993; Barro, 2000). Inequality is also strongly negatively associated with social trust (Uslaner, 2002), which thus could give rise to a spurious effect. On the other hand, wage inequality could create incentives to invest in education (see e.g. Topel, 1997). iv) Democratic systems may invest more in education to the extent that voters demand it and may also be associated with higher trust (Uslaner, 1999); hence the number of years in the period that a country has been democratic enters the pool. v) Population density may proxy for transaction costs that are particularly high in scarcely populated countries where pupils need to travel a significant distance to get to school. Given that a number of such countries have relatively low trust scores this might give rise to a spurious effect. vi) Governments' share of GDP proxies for the generosity of welfare, which may make it less risky to take an education, but could also reduce the incentives to take an education. As some authors also connect social trust and features of welfare state, this could produce a spurious effect (Rothstein, 2003). vii) Expenditure per student naturally measures actual investments in education and thus captures a supply side effect. If trust captures a ‘solidarity’ effect this might for example be reflected in educational spending. vii) Trust may proxy for growth, since a number of studies find that social trust is an important determinant of economic growth (Whiteley, 2000; Zak and Knack, 2001; Beugelsdijk et al., 2004). Growing wealth may in turn have affected the level of schooling, or might simply create a spurious correlation between trust and schooling as both are correlated with economic growth. ix) Weede and Kämpf (2002) argue that some level of intelligence is a prerequisite for education, i.e. it could also be expected to influence the growth of schooling. IQ might also pick up family effects as suggested by Coleman (1988). Finally, x) the social capital literature in general finds that social trust is associated with the quality of formal institutions and governance (Knack and Keefer, 
1997; Beugelsdijk et al., 2004). As schooling growth could possibly depend on the functioning of institutions, a measure of governance is included. ${ }^{8}$

\section{Empirical results}

Turning to the empirical association between schooling growth and social trust, a first indication of the notion brought forward by this paper can be seen in Fig. 1 that plots trust levels against the growth of average schooling length adjusted for initial levels, i.e. taking any convergence towards a long-run steady state into account as suggested by the model. ${ }^{9}$ The positive correlation is evident in the figure, which thus suggests that the lagging performance of countries such as Turkey, Venezuela and Costa Rica may be ascribed to low trust levels. Conversely, the strong relative improvements in schooling in Scandinavia, Canada and New Zealand coincide with above-average levels of social trust. The figure also indicates that Pakistan and South Korea may be outliers.

\section{INSERT FIGURE 1 ABOUT HERE}

\footnotetext{
${ }^{8}$ As outlined in Table A1, the governance index is the average of all six Kaufman indices across all time periods. Although the indices are meant to measure different aspects of governance, they are highly correlated and therefore more likely measure an overall aspect of governance. The statistical validity of averaging is evident by Cronbach’s Alpha, which is 0.98 in the present sample of countries and 0.99 in the full 1996-2002 data set.

${ }^{9}$ Note that the figure on the y-axis is schooling growth adjusted for initial levels; i.e. the residual from regressing the growth of average schooling length on its initial 1960 level.
} 
However, a simple correlation with a single indicator is not evidence of a causal effect. Table 1 therefore presents the results of regressing the growth rate of the average length of schooling between 1960 and 2000 on initial levels of schooling in 1960, the logarithm to initial GDP per capita in 1960 and social trust using ordinary least squares (OLS). The results first of all show that these variables have affected the growth of schooling as expected. The findings show a strong convergence effect, as countries with low initial levels of schooling catch up by achieving faster accumulation of education, and initial GDP per capita also receives a negative and strongly significant sign, which can be interpreted as evidence of the effect of high initial costs of investing in education in relatively rich countries (the $w_{0}$ in the model). These findings are thus consistent with the predictions of the model in equation (8).

\section{INSERT TABLE 1 ABOUT HERE}

Turning to the main point of this paper, the central implication of the model receives strong support in Table 1, as social trust emerges as an important determinant of the growth of schooling in the period 1960-2000. The table also presents the results of using the growth rate of the average schooling of female adults as the dependent variable, which shows the same pattern, although this is hardly surprising given the strong correlation between these dependent variables. Controlling for regional fixed effects reduces both coefficients as well as the significance of the coefficient on female schooling growth (columns 2 and 5) but does not affect the qualitative findings. Furthermore, to control for the possibility that the results are driven by a small group of 
outlier observations, columns 3 and 6 apply a robust regressions technique. ${ }^{10}$ This alternative approach yields a slightly larger effect of social trust on average schooling growth and a substantially larger effect on the growth of female schooling. It can thus be concluded that the results obtained by simple OLS are not likely to be driven by outlier observations. Moreover, the results are easily interpretable within the framework of the simple model brought forward in section 2.

Table 2 repeats the exercise with the growth of the share of the population with secondary schooling and the share of the population with a post-secondary education. The table shows that secondary schooling growth also seems to be associated with social trust with an effect comparable to that on average length of schooling. However, the growth of post-secondary schooling has clearly not been influenced by social trust. The former result is also robust to the inclusion of regional effects and weighting down potentially influential observations although the standardized coefficient obtained from robust regressions is rather large while the latter non-result is not influenced by outliers. The apparently significant effect in column 5 in fact turns out to be a result of outliers that is corrected for in the robust regression. ${ }^{11}$

INSERT TABLE 2 ABOUT HERE

\footnotetext{
${ }^{10}$ Robust regression takes the residuals of simple OLS and weights the influence of observations with large residuals down. Hence, if results were driven by a small group of outliers this procedure should make the coefficients on trust appear small and insignificant.

${ }^{11}$ The table does not report the results of estimating robust regressions with regional effects, as these results are in all cases virtually similar to those without such effects. Hence, the significance of social trust in column 5 is eradicated when a small number of outliers are weighted down by this technique.
} 
The findings thus provide support for the notion that social trust is associated with faster growth of average schooling and of secondary education, all other things being equal, i.e. the findings support the explanation proposed in the theoretical model. Furthermore, the results show that the effect of social trust is not driven by outlier observations. These results could nevertheless still be spurious due to two other factors. Firstly, they could be the result of omitted variables correlated with trust; and secondly, the findings could reflect the opposite casual direction, i.e. Knack and Keefer's (1997) explanation that the growth of schooling has caused the current cross-country trust differences. The latter problem may be particularly relevant as the growth of schooling is measured in the period 1960-2000 while social trust is only measured in the latter half of the period. These problems are taken into account in Tables 3 and 4.

Table 3 explores the robustness of the results to the inclusion of a set of control variables by performing a small EBA consisting of entering all combinations of one or two variables from a pool of eleven control variables, which gives a total of 66 permutations. Following Levine and Renelt (1992), a result is deemed robust if the coefficient on the variable of interest remains of the same sign and is significant at the 5\% level throughout. Although more recent work by Sala-I-Martin (1997) has criticized the Levine-Renelt approach as being too restrictive, it is used in the following since variables passing this test will in all likelihood also pass Sala-I-Martin’s criteria. As outlined above, the EBA variables are the initial fertility rate, openness to trade, market distortions, income inequality, democratic tenure, population density, governments’ share of the economy, expenditure per student, GDP growth, average intelligence (IQ), and governance. 
Performing an EBA with these control variables firstly shows that the association between social trust and the growth of average schooling length is robust in an extreme bounds sense, as reported in Table 3: the effect of social trust remains positive throughout and only fails the $1 \%$ level in one case. Furthermore, the max-min ratio - the difference between the lower bound (the smallest estimate obtained in any specification) and the upper bound (the largest estimate obtained in any specification) - is 1.6, which compared to most EBA results is rather small. When turning to the growth of female average schooling length, the results are only slightly less precise, as social trust fails the $1 \%$ level in two cases and the max-min ratio is 1.9 . With respect to the third dependent variable - the growth of the share of the population that has a secondary education - the result is also robust in the strong sense, although the inclusion of governance in general lowers the significance level to $5 \%$ while the max-min ratio is 1.8. Hence, it does not seem likely that the results are caused by omitted variables although a few results from the EBA nevertheless need mention.

It is worth noting that with all three dependent variables, the lower bound coefficients derive from specifications that include the measure of market distortions. It is also worth noting that economic growth is always significantly negative at $10 \%$ or better when the growth of average female schooling is the dependent variable. On average, specifications with economic growth also provide the highest estimates. Although puzzling, this result is consistent with e.g. Barro (1997) who finds that male schooling is positively associated while female schooling is negatively associated with growth, possibly because female schooling follows male schooling only with a lag. Expenditure per student on the other hand never approaches significance, implying that there is no evidence of any supply side effect on the growth of schooling. With respect 
to the last control variable to enter the EBA, it must be concluded that governance (or institutional quality) does not provide a transmission channel for trust, as it is never significant. It furthermore exerts no influence on the coefficient on trust, which in these specifications is virtually unchanged. ${ }^{12}$ Surprisingly, the well-functioning of formal institutions seem unrelated to schooling growth.

\section{INSERT TABLE 3 ABOUT HERE}

Finally, Table 4 addresses the issue of potential reverse causation. To sort out the direction of causality, an instrumental variables (IV) approach is adopted. ${ }^{13}$ If it were the case that part of the significant association obtained from OLS is entirely due to the reverse causality, this procedure would reduce the size of the coefficient and render it insignificant. On the other hand, if there is a positive feedback effect, i.e. a two-way causation, it could be expected that the OLS estimates were downwards biased, in which case the IV-estimates would be larger than the OLS estimates. The choice of instrument is a measure of absence of corruption, which has been shown to be significantly associated with social trust (Uslaner, 2002) while there are neither

\footnotetext{
${ }^{12}$ Alternative measures of expenditure such as educational expenditure as percentage of GDP and growth rates of these measures performed equally poorly in robustness analyses not reported here, thus failing to provide evidence of supply side effects, as found by other types of studies (Hanushek, 1986). With respect to governance, it should be noted that neither the single Kaufman indices nor alternative measures of institutional quality from the Fraser Institute (Gwartney and Lawson, 2002) proved to exert any influence.

${ }^{13}$ Although Hausman tests fail to reject that social trust is exogenous, IV estimates are reported as the test is known to be rather weak and the test results are not particularly strong (Maddala, 1992).
} 
theoretical nor empirical associations with the growth of schooling (see Table A1 for sources). ${ }^{14}$

\section{INSERT TABLE 4 ABOUT HERE}

The results of employing the instrument show that the effects of social trust are real and in the direction posited in the theoretical model, as trust remains significant at conventional levels and none of the IV estimates differ significantly from the simple OLS estimates. Hence, given that IV approaches can inform about causality at all, the results indicate that there probably is no reverse causal effect from the growth of schooling to social trust, thereby supporting the theoretical presumption that social capital in the form of trust has caused substantial improvements of education. The results are of economic significance, for example indicating that a positive shock to social trust of about 15 percentage points (one standard deviation) would have led to roughly 30\% additional growth of average schooling during the 40 -year period considered in this paper. As social trust is demonstrated to be robustly associated with schooling growth, the consequences for countries' economic and human development

\footnotetext{
${ }^{14}$ The instrument is valid, as it does not correlate with the residual from a regression without social trust but is strongly associated with such trust. The fit of the instrument in the first stage regression moreover easily passes Staiger and Stock's (1997) rule of thumb criteria for proper instruments $\left(\mathrm{R}^{2}=0.61 ; \mathrm{F}=79.91\right)$. Although the variable is measured at the end of the period, this may not constitute a problem as corruption is often found to be remarkably stable over time (see e.g. Treisman, 2000). An alternative set of instruments including the Protestant share of population, ethnic diversity and a dummy for postcommunist countries yielded very similar results that can be obtained from the author.
} 
are therefore far from negligible. The potential implications of these findings are outlined in the concluding section.

\section{Conclusions}

This paper has examined the association between social trust and schooling, relating the former to the impressive improvements of schooling in most of the world since 1960. Firstly, the paper shortly outlined two conflicting views on the connection between social trust and education proposed by previous research. Showing that there appears to be an empirical association between levels of trust and education, one strand of the literature has suggested that increased schooling makes individuals more likely to trust other people (e.g. Knack and Keefer, 1997; Knack and Zak, 2002). Another strand has instead interpreted the association to be an effect of trust leading to a higher supply of education across countries (e.g. Coleman, 1988; la Porta et al., 1997; Putnam, 2000). After a review of these contrasting explanations, the paper explored a third potential mechanism, developing a simple theoretical model with endogenous investments in labour-augmenting technology. The model illustrated an alternative mechanism where firms' demand for schooling increases as countries move towards more knowledgeintensive production as a result of these investments. While this is a trivial insight, the model also illustrated how the response of schooling demand to changes in factor intensity may be stronger in high-trust societies where transaction costs associated with finding trustworthy educated employees are relatively low. Contrary to previous research, the theoretical channel proposed in the model therefore relies on a demandside effect that leads to a faster growth of schooling in high-trust societies. 
The paper thereafter tested whether this proposition can be found in real-life data. In a sample of 52 countries, the growth of schooling was measured by the percentage improvements between 1960 and 2000 in average schooling length, average female schooling length, the share of the population receiving a secondary education, and the share of the population receiving a post-secondary education. The results of regressing schooling growth on social trust, initial schooling and initial GDP per capita provided support for the proposition that trust is positively associated with improvements in education. The finding that social trust has caused the growth of average and secondary (but not post-secondary) schooling proved to be robust to controlling for potential omitted variables and to the exclusion of potentially confounding outliers. Using an instrumental variables approach moreover indicates that the findings are not the result of reverse causality, given that such approaches can inform about causality. Indeed, the OLS estimates seem unbiased, suggesting that there is no discernable effect of schooling growth on social trust, a finding that is contrary to interpretations of the trusteducation association in some previous studies. Furthermore, the effects are sufficiently large to warrant considerable economic interest.

The empirical results suggest that investments in education are relatively cheaper in high-trust than in low-trust societies, which have led to faster growth of schooling in the former countries. The results therefore point to the possibility that part of the effect of social trust on economic growth identified in recent studies may be due to its effects on the accumulation of education. These findings could have implications for policy priorities, as low-trust countries may need to reconsider the balance between investing in schooling versus e.g. physical capital or infrastructure when trying to further their social and economic development, since trust influences how costly investments in 
schooling are. However, the findings also provide a negative implication by questioning that increased education leads to increased social trust. Since this paper rejects the finding of previous research that schooling is a determinant of trust, the potential for trust-enhancing policy identified in the recent literature remains sadly limited.

As a final remark, it must be stressed that this is a first foray into the topic and the paper consequently asks as well as answers questions. In particular, the empirical evidence does not contain information on whether the transaction costs channel suggested in the theoretical model is in fact one of the underlying factors driving the results. As such, future research could for example investigate whether social trust actually affects search costs in the labour market as assumed in the model, as well as reexamine the perhaps controversial conclusion that investments in education do not affect the levels of social trust. Given the present knowledge of the consequences of trust, the returns to research in the social and institutional determinants of both trust and education ought to be considerable. 
Appendix

INSERT TABLE A1 ABOUT HERE

INSERT TABLE A2 ABOUT HERE

The implications with respect to the steady state investment and income levels follow directly from solving firms' maximization problem. The growth of schooling follows from the steady state level in equation A1 that can also be derived directly from the maximization problem. It can easily be shown that equation A2 is positive for values of $y$ that are above the limit set out in equation A3. This is readily interpretable as a condition stating that the overall general level of development, $w_{0}$, may need to be above a certain bound in order to make it rational for firms to employ an educated workforce. Hence, only when this condition is satisfied does the model replicate the strong empirical association between social trust and the level of education.

$$
\begin{aligned}
& l=\left[\left(\frac{w_{0}}{\delta}\right)^{\frac{\delta}{\beta}}\left(\frac{1+r}{\mu \beta} b\right)^{\frac{1-\delta}{\beta}} \frac{1}{Q}\right]^{\frac{1}{\alpha}} \\
& Q=\left[\frac{\mu \beta}{\delta} \frac{w_{0}}{1+r}-1\right][\omega(1-\sigma)+\sigma]+\frac{(1-\omega)(1-\sigma)(1+r)}{\mu \beta \delta} b^{2} \\
& y>\frac{\delta}{2 b}[\omega(1-\sigma)+\sigma]+\sqrt{\left(\frac{\delta}{2 b}[\omega(1-\sigma)+\sigma]\right)^{2}-\frac{w_{0}}{(1-\omega)(1-\sigma)}}
\end{aligned}
$$


The condition referred to in a footnote on when a poverty trap appears in the model is outlined in equation A4. Finally, if there is no public and service sectors, it implies that $n=1-m$ if e.g. the model is thought of as an overlapping generations (OLG) model. It is here important to note that firms in monopolistic competition are too small to take this equality into account. Given the structure of an OLG model where individuals live for two periods and invest in education in the first period, one can solve for the equilibrium level of $w_{0}$. Equation A5 thus follows from the maximization problem and the poverty trap in equation A3 arises as an effect of fast discounting of the future. More specifically, it can easily be shown that the poverty trap arises when equation A6 is fulfilled. In the poverty trap, the economy is thus trapped in a corner solution of the model where schooling cannot fall below zero or some preset limit. This eradicates the incentive to invest and the economy then stagnates at some level of $y$.

$$
\begin{aligned}
& \omega<1-\frac{\mu \beta \delta}{2(1+r)(1-\sigma)} \\
& w_{0}=\frac{2 \delta y}{\sqrt{5}-1} \\
& w_{0}<\delta\left(\frac{2}{\sqrt{5}-1}-\frac{1}{b}\right)
\end{aligned}
$$




\section{References}

Ahn, T.K., Ostrom, E. (2002). Social capital and the second-generation theories of collective action: An analytical approach to the forms of social capital. Paper presented at the annual meeting of the American Political Science Association, Boston, August. Barro, R.J. (1997). Determinants of economic growth: a cross-country empirical study. Cambridge, MA, MIT Press.

Barro, R.J. (2000). Inequality and growth in a panel of countries. Journal of Economic Growth 5 (1), 5-32.

Barro, R.J., \& Lee, J-W. (2001). International data on educational attainment: updates and implications. Oxford Economic Papers 53, 541-63.

Bassanini, A., \& Scarpetta, S. (2002). Does human capital matter for growth in OECD countries? A pooled mean-group approach. Economics Letters 74, 399-405.

Becker, G.S., \& Murphy, K.M. (1992). The division of labor, coordination costs, and knowledge. Quarterly Journal of Economics 107, 1137-60.

Berggren, N., \& Jordahl, H. (2006). Free to trust? Economic freedom and social capital. Kyklos 59, 141-169.

Beugelsdijk, S., de Groot, H.L.F., \& van Schaik, A.B.T.M. (2004). Trust and economic growth: a robustness analysis. Oxford Economic Papers 56, 118-34.

Bjørnskov, C. (2006). The multiple facets of social capital. European Journal of Political Economy 22, 22-40.

Bjørnskov, C. (2007). Determinants of generalized trust. A cross-country comparison. Public Choice 130, 1-21.

Bourdieu, P. (1986). The forms of capital. In: J.G. Richardson, Handbook of Theory and Research for the Sociology of Education. New York, Greenwood Press. 
Carpenter, J.P. (2002). Measuring social capital: adding field experimental methods to the analytical toolbox. In J. Isham, Kelly, T., \& Ramaswamy, S., Social capital, economic development and the environment. Well-being in developing countries. Northampton, MA., Edward Elgar.

Coleman, J. (1988). Social capital in the creation of human capital. American Journal of Sociology 98, S95-120.

Deininger, K., \& Squire, L. (1996). A new data set measuring income inequality. World Bank Economic Review 10, 565-69.

Deutsch, M. (1958). Trust and suspicion. Journal of Conflict Resolution 2, 265-279.

Dufwenberg, M., \& Gneezy, U. (2000). Measuring beliefs in an experimental lost wallet game. Games and Economic Behaviour 30, 163-82.

Fine, B. (2001). Social capital versus social theory. London, Routledge.

Forbes, K. (2000). A reassessment of the relation between inequality and growth. American Economic Review 90, 869-87.

Fukuyama, F. (1995). Trust. The social virtues and creation of prosperity. London, Hamish Hamilton.

Glaeser, E.L., Laibson, D., Scheinkman, J.A., \& Soutter, C.L. (2000). Measuring trust. Quarterly Journal of Economics 115, 811-46.

Gradstein, M., \& Justman, M. (2000). Human capital, social capital, and public schooling. European Economic Review 44, 879-890.

Grafton, R.Q., Knowles, S., \& Owen, P.D. (2002). Social divergence and productivity: making a connection. Review of Economic Performance \& Social Progress 2, 203-23. Guerra, G., \& Zizzo, D.J. (2004). Trust responsiveness and beliefs. Journal of Economic Behavior and Organization 5, 25-30. 
Gwartney, J., \& Lawson, R. (2001). Economic freedom of the world: 2001 annual report. Vancouver, the Fraser Institute.

Hanushek, E.A. (1986). The economics of schooling: production and efficiency in public schools. Journal of Economic Literature 24, 1141-77.

Hanushek, E.A., \& Luque, J.A. (2003). Equity and efficiency in schools around the world. Economics of Education Review 20, 481-502.

Heston, A., Summers, R., \& Aten, B. (2002). Penn world tables version 6.1. University of Pennsylvania, Center for International Comparisons.

Inglehart, R., Basañez, M., \& Moreno, A. (1998). Human Values and Beliefs. A CrossCultural Sourcebook. Ann Arbor, University of Michigan Press.

Jacobs, J. (1961). The Death and Life of Great American Cities. New York, Random House.

Kaufmann, D., Kraay, A., \& Mastruzzi, M. (2003). Governance matters III: Governance indicators for 1996-2002. World Bank Policy Research Working Paper 3106.

Knack, S. (2001). Trust, associational life and economic performance. In: J.F. Helliwell, The contribution of human and social capital to sustained economic growth and wellbeing: international symposium report. Quebec, Human Resources Development Canada.

Knack, S. Groups, growth and trust: cross-country evidence on the Olson and Putnam hypotheses. Public Choice 2003; 117; 341-55.

Knack, S., \& Keefer, P. (1997). Does social capital have an economic pay-off? A crosscountry investigation. Quarterly Journal of Economics 112, 1251-88.

Knack, S., \& Zak, P.J. (2002). Building trust: public policy, interpersonal trust, and economic development. Supreme Court Economic Review 10, 91-107. 
La Porta, R., Lopez-de-Silanes, F., Schleifer, A., \& Vishny, R.W. (1997). Trust in large organizations. American Economic Review 87, 333-8.

Leamer, E. (1985). Sensitivity analyses would help. American Economic Review 75, 308-313.

Lederman, D., Loayza, N., \& Menéndez, A.M. (2002). Violent crime: does social capital matter? Economic Development and Cultural Change 50, 509-39.

Levine, R., \& Renelt, D. (1992). A sensitivity analysis of cross-country growth regressions. American Economic Review 82, 942-63.

Loury, G. (1977). A dynamic theory of racial income differences. In: P. Wallace, \& LaMond, A, Women, minorities, and employment. Lexington, MA, Heath.

Lynn, R., \& Vanhanen, T. (2002). IQ and the wealth of nations. Westport, Praeger. Maddala, G.S. (1992). Introduction to Econometrics, $2^{\text {nd }}$ Edition. Englewood Cliffs, NJ, Prentice-Hall.

Milgrom, P., \& Roberts, J. (1992). Economics, organization and management.

Englewood Cliffs, NJ, Prentice-Hall.

Perotti, R. (1993). Political equilibrium, income distribution, and growth. Review of Economic Studies 60, 755-76.

Putnam, R. (1993). Making democracy work. Civic traditions in modern Italy.

Princeton, NJ, Princeton University Press.

Putnam, R. (2000) Bowling alone. The collapse and revival of American community. New York, Simon and Schuster.

Rainer, H. \& Siedler, T. (2006). Does democracy foster trust? IZA Discussion paper 2154, Institute for the Study of Labor, Bonn. 
Rothstein, B. (2003). Social capital, economic growth and quality of government. New Political Economy 8, 49-72.

Sala-I-Martin, X. (1997). I just ran two million regressions. American Economic Review 87, 178-83.

Schneider, M., Teske, P., Marschall, M., Mintrom, M., \& Roch, C. (1997). Institutional arrangements and the creation of social capital: the effects of public school choice. American Political Science Review 91, 82-93.

Staiger, D., \& Stock, J.H. (1997). Instrumental variables regression with weak instruments. Econometrica 65, 557-86.

Summers, R., \& Heston, A. (1991). The Penn world tables (mark 5): an expanded set of international comparisons, 1950-1988. Quarterly Journal of Economics 106, 327-68. Teachman, J.D., Paasch, K., \& Carver, K. (1997). Social capital and the generation of human capital. Social Forces 75, 1343-59.

Topel, R.H. (1997). Factor proportions and relative wages: the supply-side determinants of wage inequality. Journal of Economic Perspectives 11, 55-74.

Transparency International. (2003). Transparency international corruption perceptions index 2003. Press release (October), Berlin, Transparency International. Treisman, D. (2000). The causes of corruption: a cross-national study. Journal of Public Economics 76, 399-457.

UNDP. (2003). Human development report 2003. New York, United Nations Development Program. Uslaner, E.M. (1999). Democracy and social capital. In: M. Warren, M, Democracy and Trust. Cambridge, UK, Cambridge University Press. 
Uslaner, E.M. (2002). The Moral Foundations of Trust. Cambridge, UK, Cambridge University Press.

Volken, T. (2002). Generalisiertes Vertrauen: Zur Reliabilität und Validität eines verbreiteten Messinstruments in Wirtschaftssoziologisches Forschungszusammenhängen. Mimeo, University of Zürich. Wacziarg, R. (2001). Measuring the dynamic gains from trade. World Bank Economic Review 15, 393-429.

Weede, E., \& Kämpf, S. (2002). The impact of intelligence and institutional improvement on economic growth. Kyklos 55, 361-80.

Whiteley, P. (2000). Economic growth and social capital. Political Studies 48, 443-66. World Bank. (2003). World Development Indicators. CD-ROM and on-line database, Washington DC, the World Bank.

Zak, P.J., \& Knack, S. (2001). Trust and growth. The Economic Journal 111, 295-321. 
Table 1. Social trust and growth of average schooling

\begin{tabular}{|c|c|c|c|c|c|c|}
\hline \multirow[t]{2}{*}{ Growth variable } & \multicolumn{3}{|c|}{ Average schooling length } & \multicolumn{3}{|c|}{ Female average schooling length } \\
\hline & 1 & 2 & 3 & 4 & 5 & 6 \\
\hline Estimation method & OLS & OLS & Robust & OLS & OLS & Robust \\
\hline \multirow[t]{2}{*}{ Initial schooling } & $-0.696 * * *$ & $-0.643^{* * *}$ & $-0.880 * * *$ & $-0.492 * * *$ & $-0.450 * * *$ & $-0.912 * * *$ \\
\hline & $(-5.296)$ & $(-5.108)$ & $(-13.992)$ & $(-3.365)$ & $(-3.109)$ & $(-6.933)$ \\
\hline \multirow[t]{2}{*}{ Initial GDP per capita } & $-0.375^{* * *}$ & $-0.331 * *$ & $-0.367 * * *$ & $-0.567 * * *$ & $-0.485 * * *$ & $-0.589 * * *$ \\
\hline & $(-3.015)$ & $(-2.532)$ & $(-6.789)$ & $(-4.076)$ & $(-3.197)$ & $(-6.094)$ \\
\hline \multirow[t]{2}{*}{ Social trust } & $0.373 * * *$ & $0.283^{* * *}$ & $0.430 * * *$ & $0.379 * * *$ & $0.212^{*}$ & $0.657 * * *$ \\
\hline & $(3.975)$ & $(2.838)$ & $(8.568)$ & $(3.788)$ & $(1.931)$ & $(6.446)$ \\
\hline Regional dummies & No & Yes & No & No & Yes & No \\
\hline Observations & 52 & 52 & 51 & 50 & 50 & 50 \\
\hline Adjusted R square & 0.710 & 0.784 & 0.923 & 0.689 & 0.751 & 0.887 \\
\hline F statistic & 42.694 & 27.381 & 20.4568 & 37.115 & 22.111 & 128.927 \\
\hline
\end{tabular}


Table 2. Social trust and growth of additional schooling

\begin{tabular}{|c|c|c|c|c|c|c|}
\hline \multirow[t]{2}{*}{ Growth variable } & \multicolumn{3}{|c|}{ Secondary schooling } & \multicolumn{3}{|c|}{ Post-secondary education } \\
\hline & 1 & 2 & 3 & 4 & 5 & 6 \\
\hline Estimation method & OLS & OLS & Robust & OLS & OLS & Robust \\
\hline Initial schooling & $\begin{array}{c}-0.608 * * * \\
(-4.731)\end{array}$ & $\begin{array}{c}-0.572 * * * \\
(-4.869)\end{array}$ & $\begin{array}{c}-0.665 * * * \\
(-9.433)\end{array}$ & $\begin{array}{c}-0.648 * * * \\
(4.613)\end{array}$ & $\begin{array}{c}-0.595 * * * \\
(-4.479)\end{array}$ & $\begin{array}{c}-0.786 * * * \\
(-7.436)\end{array}$ \\
\hline Initial GDP per capita & $\begin{array}{c}-0.395 * * * \\
(-3.019)\end{array}$ & $\begin{array}{c}-0.527 * * * \\
(-3.242)\end{array}$ & $\begin{array}{c}-0.634 * * * \\
(-9.417)\end{array}$ & $\begin{array}{c}0.065 \\
(0.415)\end{array}$ & $\begin{array}{l}-0.186 \\
(-0.889)\end{array}$ & $\begin{array}{c}0.130 \\
(1.001)\end{array}$ \\
\hline Social trust & $\begin{array}{c}0.430 * * * \\
(3.420)\end{array}$ & $\begin{array}{c}0.461 * * * \\
(3.450)\end{array}$ & $\begin{array}{c}0.510 * * * \\
(8.078)\end{array}$ & $\begin{array}{c}0.130 \\
(0.834)\end{array}$ & $\begin{array}{l}0.307 * \\
(1.805)\end{array}$ & $\begin{array}{c}0.122 \\
(0.927)\end{array}$ \\
\hline Regional dummies & No & Yes & No & No & Yes & No \\
\hline Observations & 50 & 50 & 50 & 48 & 48 & 48 \\
\hline Adjusted R square & 0.500 & 0.591 & 0.886 & 0.296 & 0.402 & 0.528 \\
\hline F statistic & 17.353 & 11.130 & 127.880 & 7.958 & 5.507 & 18.509 \\
\hline
\end{tabular}


Table 3. Social trust and growth of schooling, robustness

\begin{tabular}{|c|c|c|c|c|c|c|}
\hline \multirow[t]{2}{*}{ Growth variable } & \multicolumn{2}{|c|}{ Average schooling length } & \multicolumn{2}{|c|}{ Female average schooling length } & \multicolumn{2}{|c|}{ Secondary schooling } \\
\hline & Lower bound & Upper bound & Lower bound & Upper bound & Lower bound & Upper bound \\
\hline \multirow[t]{2}{*}{ Initial schooling } & $-0.607 * * *$ & $-0.960 * * *$ & $-0.422 * * *$ & $-0.745 * * *$ & $-0.542 * * *$ & $-0.802^{* * *}$ \\
\hline & $(-4.253)$ & $(-8.991)$ & $(-2.832)$ & $(-4.985)$ & $(-3.982)$ & $(-6.166)$ \\
\hline \multirow[t]{2}{*}{ Initial GDP per capita } & -0.107 & $-0.625 * * *$ & $-0.276 *$ & $-0.803 * * *$ & -0.094 & $-0.611 * * *$ \\
\hline & $(-1.007)$ & $(-3.739)$ & $(-1.917)$ & $(-4.644)$ & $(-0.528)$ & $(-4.149)$ \\
\hline \multirow[t]{2}{*}{ Social trust } & $0.314 * *$ & $0.506 * * *$ & $0.289 * * *$ & $0.544 * * *$ & $0.335^{* *}$ & $0.614^{* * *}$ \\
\hline & $(2.361)$ & $(4.464)$ & $(2.761)$ & $(5.032)$ & $(2.369)$ & $(4.165)$ \\
\hline
\end{tabular}

Note: all regressions include a constant term; coefficients are standardized; t-statistics in parentheses; *** denotes significance at $\mathrm{p}<0.01$; $* *$ at $\mathrm{p}<0.05 ; *$ at $\mathrm{p}<0.10$. 
Table 4. Social trust and growth of schooling, IV estimates

\begin{tabular}{lccc}
\hline Growth variable & $\begin{array}{c}\text { Average schooling } \\
\text { length }\end{array}$ & $\begin{array}{c}\text { Female average } \\
\text { schooling length }\end{array}$ & Secondary schooling \\
& 1 & 3 & 5 \\
Estimation method & IV & IV & IV \\
\hline Initial schooling & $-0.676^{* * *}$ & $-0.453^{* * *}$ & $-0.619^{* * *}$ \\
& $(-4.750)$ & $(2.867)$ & $-4.512)$ \\
Initial GDP per capita & $-0.366^{* * *}$ & $-0.559^{* * *}$ & $\left(-2.761^{* * *}\right.$ \\
& $(2.865)$ & $(3.872)$ & $0.465^{* *}$ \\
Social trust & $0.325^{* *}$ & $0.301^{*}$ & $(2.364)$ \\
& $(2.289)$ & $(1.962)$ & 48 \\
Observations & 50 & 48 & 0.465 \\
Adjusted R square & 0.688 & 0.661 & 14.883 \\
F statistic & 37.806 & 32.256 & \\
\hline Note: all regressions include a constant term; coefficients are standardized; t-statistics in parentheses; *** \\
denotes significance at $\mathrm{p}<0.01 ; * *$ at $\mathrm{p}<0.05 ; *$ at $\mathrm{p}<0.10$. The instrument for social trust in IV-estimation \\
is absence of corruption.
\end{tabular}


Table A1. Variable sources and definitions

\begin{tabular}{|c|c|c|}
\hline Name & Source & Definition \\
\hline Average schooling length & Barro and Lee (2001) & Average number of years adults over age 25 attended school; initial level is 1960. \\
\hline Average female schooling length & Barro and Lee (2001) & Average number of years female adults over age 25 attended school; initial level is 1960 . \\
\hline Secondary schooling & Barro and Lee (2001) & Share of population with secondary schooling; initial level is 1960. \\
\hline Post-secondary schooling & Barro and Lee (2001) & Share of population with tertiary schooling; initial level is 1960. \\
\hline Schooling growth & Barro and Lee (2001) & Percentage growth of one of four schooling measures, 1960-2000. \\
\hline GDP per capita & Heston, Summers \& Aten (2002) & $\begin{array}{l}\text { GDP per capita, purchasing power adjusted. For a description of the approach, see Summers } \\
\text { and Heston (1991). }\end{array}$ \\
\hline Social trust & $\begin{array}{l}\text { Inglehart, Basañez \& Moreno } \\
\text { (1998) }\end{array}$ & $\begin{array}{l}\text { Percentage of population saying yes to “In general, do you think most people can be trusted } \\
\text { or can't you be too careful?” These data are supplemented in two cases (Costa Rica and } \\
\text { Ecuador) with similar data from the ongoing Danish Social Capital project. All are averages } \\
\text { of all available observations. }\end{array}$ \\
\hline Fertility rate & World Bank (2003) & Number of children born per woman, 1960. \\
\hline Openness & Heston et al. (2002) & Export plus imports as \% of GDP, purchasing power adjusted. \\
\hline Market distortions & Heston et al. (2002) & Price of investments relative to the US, purchasing power adjusted. \\
\hline Inequality & Deininger and Squire (1996) & Income inequality measured by Gini coefficient. \\
\hline Democratic tenure & Gwartney and Lawson (2001) & Number of years country has been democratic in period 1960-2000. \\
\hline Population density & World Bank (2003) & Average number of inhabitants per square kilometre. \\
\hline Government share of economy & Heston et al. (2002) & Share of government activities in GDP. \\
\hline Expenditure per student & World Bank (2003) & Average expenditure per student enrolled in primary school. \\
\hline GDP growth & Heston et al. (2002) & Average yearly percentage growth of GDP, purchasing power adjusted. \\
\hline Average IQ & Lynn and Vanhanen (2002) & Average intelligence obtained from intelligence tests. \\
\hline Governance & $\begin{array}{l}\text { Kaufmann, Kraay \& Mastruzzi } \\
\text { (2003) }\end{array}$ & Average of six indicators of good governance across all available time periods. \\
\hline Absence of corruption & Transparency International (2003) & Absence of corruption measured from 0 (all-pervasive corruption) to 10 (no corruption). \\
\hline
\end{tabular}


Table A2. Descriptive statistics

\begin{tabular}{lccc}
\hline Name & Mean & Standard deviation & Observations \\
\hline Average schooling, 1960 & 5.02 & 2.39 & 52 \\
Average female schooling, 1960 & 4.64 & 2.57 & 50 \\
Secondary schooling, 1960 & 9.99 & 8.77 & 50 \\
Post- secondary schooling, 1960 & 2.25 & 2.15 & 50 \\
Average schooling growth & .89 & .84 & 52 \\
Female schooling growth & 1.41 & 1.94 & 50 \\
Secondary schooling growth & 3.50 & 3.29 & 48 \\
Post-secondary schooling growth & 6.05 & 4.86 & 48 \\
GDP per capita & 5,699 & 3,724 & 52 \\
Social trust & 29.20 & 14.93 & 52 \\
Fertility rate & 4.21 & 1.92 & 50 \\
Openness & 53.39 & 33.97 & 52 \\
Market distortions & -0.08 & 0.29 & 52 \\
Inequality & 37.19 & 10.20 & 48 \\
Democratic tenure & 25.81 & 13.29 & 52 \\
Population density & 141.51 & 197.71 & 52 \\
Government share of economy & 16.68 & 6.90 & 52 \\
Expenditure per student & 14.55 & 6.89 & 48 \\
GDP growth & 0.10 & 0.10 & 52 \\
Average IQ & 93.46 & 8.09 & 52 \\
Governance & 0.75 & 0.86 & 52 \\
Absence of corruption & 5.57 & 2.50 & 51 \\
\hline
\end{tabular}


Table A3. Countries and social trust scores

\begin{tabular}{lclc}
\hline Country & Trust & Country & Trust \\
\hline Argentina & 20.8 & Italy & 31.4 \\
Australia & 43.8 & Japan & 42.9 \\
Austria & 32.8 & Malta & 20.7 \\
Bangladesh & 22.2 & Mexico & 25.1 \\
Belgium & 31.4 & Netherlands & 53.9 \\
Brazil & 4.8 & New Zealand & 49.1 \\
Bulgaria & 28.6 & Norway & 63.9 \\
Canada & 46.9 & Pakistan & 25.7 \\
Chile & 22.5 & Peru & 7.8 \\
Colombia & 10.8 & Philippines & 6.9 \\
Costa Rica & 7.4 & Poland & 23.7 \\
Croatia & 21.0 & Portugal & 15.7 \\
Czech Republic & 27.5 & Romania & 14.9 \\
Denmark & 60.1 & Slovakia & 21.9 \\
Dominican Republic & 26.4 & Slovenia & 18.2 \\
Ecuador & 8.9 & South Africa & 22.2 \\
El Salvador & 14.6 & South Korea & 32.5 \\
Finland & 56.4 & Spain & 33.6 \\
France & 23.3 & Sweden & 62.3 \\
Germany & 36.1 & Switzerland & 42.1 \\
Ghana & 22.4 & Taiwan & 38.2 \\
Greece & 23.7 & Turkey & 10.4 \\
Hungary & United Kingdom & 36.9 \\
Iceland & 25.6 & Uruguay & 22.1 \\
India & 41.5 & USA & 42.1 \\
Ireland & 38.3 & Venezuela & 14.8 \\
\hline & 41.2 & & \\
\hline
\end{tabular}


Fig. 1. Social trust and the growth of average schooling length

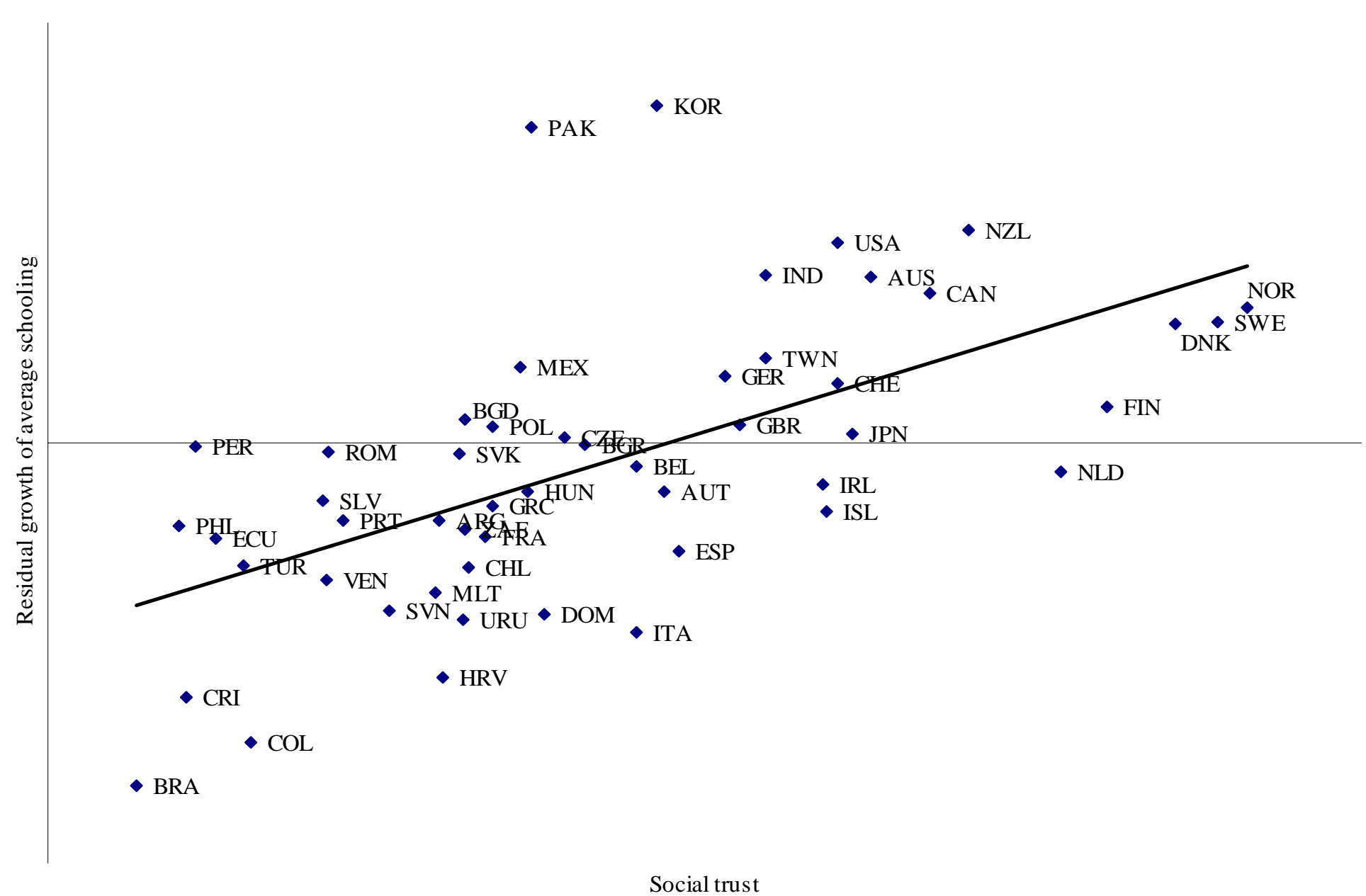


Department of Economics:

Skriftserie/Working Paper:

2003:

WP 03-1 Søren Harck: Er der nu en strukturelt bestemt langsigts-ledighed i SMEC?: Phillipskurven i SMEC 99 vis-à-vis SMEC 94. ISSN 1397-4831.

WP 03-2 Beatrice Schindler Rangvid: Evaluating Private School Quality in Denmark. ISSN 1397-4831.

WP 03-3 Tor Eriksson: Managerial Pay and Executive Turnover in the Czech and Slovak Republics. ISSN 1397-4831.

WP 03-4 Michael Svarer and Mette Verner: Do Children Stabilize Marriages? ISSN 1397-4831.

WP 03-5 Christian Bjørnskov and Gert Tinggaard Svendsen: Measuring social capital - Is there a single underlying explanation? ISSN 1397-4831.

WP 03-6 Vibeke Jakobsen and Nina Smith: The educational attainment of the children of the Danish 'guest worker' immigrants. ISSN 1397-4831.

WP 03-7 Anders Poulsen: The Survival and Welfare Implications of Altruism When Preferences are Endogenous. ISSN 1397-4831.

WP 03-8 Helena Skyt Nielsen and Mette Verner: Why are Well-educated Women not Full-timers? ISSN 1397-4831.

WP 03-9 Anders Poulsen: On Efficiency, Tie-Breaking Rules and Role Assignment Procedures in Evolutionary Bargaining. ISSN 13974831.

WP 03-10 Anders Poulsen and Gert Tinggaard Svendsen: Rise and Decline of Social Capital

- Excess Co-operation in the One-Shot Prisoner's Dilemma Game. ISSN 1397-4831. 
WP 03-11 Nabanita Datta Gupta and Amaresh Dubey: Poverty and Fertility: An Instrumental Variables Analysis on Indian Micro Data. ISSN 1397-4831.

WP 03-12 Tor Eriksson: The Managerial Power Impact on Compensation Some Further Evidence. ISSN 1397-4831.

WP 03-13 Christian Bjørnskov: Corruption and Social Capital. ISSN 13974831.

WP 03-14 Debashish Bhattacherjee: The Effects of Group Incentives in an Indian Firm

- Evidence from Payroll Data. ISSN 1397-4831.

WP 03-15 Tor Eriksson och Peter Jensen: Tidsbegränsade anställninger danska erfarenheter. ISSN 1397-4831.

WP 03-16 Tom Coupé, Valérie Smeets and Frédéric Warzynski: Incentives, Sorting and Productivity along the Career: Evidence from a Sample of Top Economists. ISSN 1397-4831.

WP 03-17 Jozef Koning, Patrick Van Cayseele and Frédéric Warzynski: The Effects of Privatization and Competitive Pressure on Firms' Price-Cost Margins: Micro Evidence from Emerging Economies. ISSN 1397-4831.

WP 03-18 Urs Steiner Brandt and Gert Tinggaard Svendsen: The coalition of industrialists and environmentalists in the climate change issue. ISSN 1397-4831.

WP 03-19 Jan Bentzen: An empirical analysis of gasoline price convergence for 20 OECD countries. ISSN 1397-4831.

WP 03-20 Jan Bentzen and Valdemar Smith: Regional income convergence in the Scandinavian countries. ISSN 1397-4831.

WP 03-21 Gert Tinggaard Svendsen: Social Capital, Corruption and Economic Growth: Eastern and Western Europe. ISSN 13974831.

WP 03-22 Jan Bentzen and Valdemar Smith: A Comparative Study of Wine Auction Prices: Mouton Rothschild Premier Cru Classé. ISSN 1397-4831. 
WP 03-23 Peter Guldager: Folkepensionisternes incitamenter til at arbejde. ISSN 1397-4831.

WP 03-24 Valérie Smeets and Frédéric Warzynski: Job Creation, Job Destruction and Voting Behavior in Poland. ISSN 1397-4831.

WP 03-25 Tom Coupé, Valérie Smeets and Frédéric Warzynski: Incentives in Economic Departments: Testing Tournaments? ISSN 13974831.

WP 03-26 Erik Strøjer Madsen, Valdemar Smith and Mogens DillingHansen: Industrial clusters, firm location and productivity Some empirical evidence for Danish firms. ISSN 1397-4831.

WP 03-27 Aycan Çelikaksoy, Helena Skyt Nielsen and Mette Verner: Marriage Migration: Just another case of positive assortative matching? ISSN 1397-4831.

2004:

WP 04-1 Elina Pylkkänen and Nina Smith: Career Interruptions due to Parental Leave - A Comparative Study of Denmark and Sweden. ISSN 1397-4831.

WP 04-2 Urs Steiner Brandt and Gert Tinggaard Svendsen: Switch Point and First-Mover Advantage: The Case of the Wind Turbine Industry. ISSN 1397-4831.

WP 04-3 Tor Eriksson and Jaime Ortega: The Adoption of Job Rotation: Testing the Theories. ISSN 1397-4831.

WP 04-4 Valérie Smeets: Are There Fast Tracks in Economic Departments? Evidence from a Sample of Top Economists. ISSN 1397-4831.

WP 04-5 Karsten Bjerring Olsen, Rikke Ibsen and Niels WestergaardNielsen: Does Outsourcing Create Unemployment? The Case of the Danish Textile and Clothing Industry. ISSN 1397-4831.

WP 04-6 Tor Eriksson and Johan Moritz Kuhn: Firm Spin-offs in Denmark 1981-2000 - Patterns of Entry and Exit. ISSN 13974831. 
WP 04-7 Mona Larsen and Nabanita Datta Gupta: The Impact of Health on Individual Retirement Plans: a Panel Analysis comparing Self-reported versus Diagnostic Measures. ISSN 1397-4831.

WP 04-8 Christian Bjørnskov: Inequality, Tolerance, and Growth. ISSN 1397-4831.

WP 04-9 Christian Bjørnskov: Legal Quality, Inequality, and Tolerance. ISSN 1397-4831.

WP 04-10 Karsten Bjerring Olsen: Economic Cooperation and Social Identity: Towards a Model of Economic Cross-Cultural Integration. ISSN 1397-4831.

WP 04-11 Iben Bolvig: Within- and between-firm mobility in the low-wage labour market. ISSN 1397-4831.

WP 04-12 Odile Poulsen and Gert Tinggaard Svendsen: Social Capital and Market Centralisation: A Two-Sector Model. ISSN 1397-4831.

WP 04-13 Aditya Goenka and Odile Poulsen: Factor Intensity Reversal and Ergodic Chaos. ISSN 1397-4831.

WP 04-14 Jan Bentzen and Valdemar Smith: Short-run and long-run relationships in the consumption of alcohol in the Scandinavian countries.

ISBN 87-7882-010-3 (print); ISBN 87-7882-011-1 (online).

WP 04-15 Jan Bentzen, Erik Strøjer Madsen, Valdemar Smith and Mogens Dilling-Hansen: Persistence in Corporate Performance? Empirical Evidence from Panel Unit Root Tests.

ISBN 87-7882-012-X (print); ISBN 87-7882-013-8 (online).

WP 04-16 Anders U. Poulsen and Jonathan H.W. Tan: Can Information Backfire? Experimental Evidence from the Ultimatum Game. ISBN 87-7882-014-6 (print); ISBN 87-7882-015-4 (online).

WP 04-17 Werner Roeger and Frédéric Warzynski: A Joint Estimation of Price-Cost Margins and Sunk Capital: Theory and Evidence from the European Electricity Industry.

ISBN 87-7882-016-2 (print); ISBN 87-7882-017-0 (online). 
WP 04-18 Nabanita Datta Gupta and Tor Eriksson: New workplace practices and the gender wage gap.

ISBN 87-7882-018-9 (print); ISBN 87-7882-019-7 (online).

WP 04-19 Tor Eriksson and Axel Werwatz: The Prevalence of Internal Labour Markets - New Evidence from Panel Data.

ISBN 87-7882-020-0 (print); ISBN 87-7882-021-9 (online).

WP 04-20 Anna Piil Damm and Michael Rosholm: Employment Effects of Dispersal Policies on Refugee Immigrants: Empirical Evidence. ISBN 87-7882-022-7 (print); ISBN 87-7882-023-5 (online).

2005:

WP 05-1 Anna Piil Damm and Michael Rosholm: Employment Effects of Dispersal Policies on Refugee Immigrants: Theory.

ISBN 87-7882-024-3 (print); ISBN 87-7882-025-1 (online).

WP 05-2 Anna Piil Damm: Immigrants’ Location Preferences: Exploiting a Natural Experiment.

ISBN 87-7882-036-7 (print); ISBN 87-7882-037-5 (online).

WP 05-3 Anna Piil Damm: The Danish Dispersal Policy on Refugee Immigrants 1986-1998: A Natural Experiment? ISBN 87-7882-038-3 (print); ISBN 87-7882-039-1 (online).

WP 05-4 Rikke Ibsen and Niels Westergaard-Nielsen: Job Creation and Destruction over the Business Cycles and the Impact on Individual Job Flows in Denmark 1980-2001.

ISBN 87-7882-040-5 (print); ISBN 87-7882-041-3 (online).

WP 05-5 Anna Maria Kossowska, Nina Smith, Valdemar Smith and Mette Verner: Til gavn for bundlinjen - Forbedrer kvinder i topledelse og bestyrelse danske virksomheders bundlinje?

ISBN 87-7882-042-1 (print); ISBN 87-7882-043-X (online).

WP 05-6 Odile Poulsen and Gert Tinggaard Svendsen: The Long and Winding Road: Social Capital and Commuting.

ISBN 87-7882-044-8 (print); ISBN 87-7882-045-6 (online).

WP 05-7 Odile Poulsen and Gert Tinggaard Svendsen: Love Thy Neighbor: Bonding versus Bridging Trust.

ISBN 87-7882-062-6 (print); ISBN 87-7882-063-4 (online). 
WP 05-8 Christian Bjørnskov: Political Ideology and Economic Freedom. ISBN 87-7882-064-2 (print); ISBN 87-7882-065-0 (online).

WP 05-9 Sebastian Buhai and Coen Teulings: Tenure Profiles and Efficient Separation in a Stochastic Productivity Model. ISBN 87-7882-066-9 (print); ISBN 87-7882-067-7 (online).

WP 05-10 Christian Grund and Niels Westergård-Nielsen: Age Structure of the Workforce and Firm Performance.

ISBN 87-7882-068-5 (print); ISBN 87-7882-069-3 (online).

WP 05-11 Søren Harck: AD-AS på dansk.

ISBN 87-7882-070-7 (print); ISBN 87-7882-071-5 (online).

WP 05-12 Søren Harck: Hviler Dansk Økonomi på en Cobb-Douglas teknologi?

ISBN 87-7882-092-8 (print); ISBN 87-7882-093-6 (online).

2006:

WP 06-1 Nicolai Kristensen and Edvard Johansson: New Evidence on Cross-Country Differences in Job Satisfaction Using Anchoring Vignettes.

ISBN 87-7882-094-4 (print); ISBN 87-7882-095-2 (online).

WP 06-2 Christian Bjørnskov: How Does Social Trust Affect Economic Growth?

ISBN 87-7882-096-0 (print); ISBN 87-7882-097-9 (online).

WP 06-3 Jan Bentzen, Erik Strøjer Madsen and Valdemar Smith: The Growth Opportunities for SMEs?

ISBN 87-7882-098-7 (print); ISBN 87-7882-099-5 (online).

WP 06-4 Anna Piil Damm: Ethnic Enclaves and Immigrant Labour Market Outcomes: Quasi-Experimental Evidence. ISBN 87-7882-100-2 (print); ISBN 87-7882-101-0 (online).

WP 06-5 Svend Jespersen, Nicolai Kristensen og Lars Skipper: En kritik af VEU-udvalgets arbejde.

ISBN 87-7882-159-2 (print); ISBN 87-7882-160-6 (online).

WP 06-6 Kræn Blume and Mette Verner: Welfare Dependency among Danish Immigrants.

ISBN 87-7882-161-4 (print); ISBN 87-7882-162-2 (online). 
WP 06-7 Jürgen Bitzer, Wolfram Schrettl and Philipp J.H. Schröder: Intrinsic Motivation versus Signaling in Open Source Software Development. ISBN 87-7882-163-0 (print); ISBN 87-7882-164-9 (online).

WP 06-8 Valérie Smeets, Kathryn Ierulli and Michael Gibbs: Mergers of Equals \& Unequals.

ISBN 87-7882-165-7 (print); ISBN 87-7882-166-5 (online).

WP 06-9 Valérie Smeets: Job Mobility and Wage Dynamics.

ISBN 87-7882-167-3 (print); ISBN 87-7882-168-1 (online).

WP 06-10 Valérie Smeets and Frédéric Warzynski: Testing Models of Hierarchy: Span of Control, Compensation and Career Dynamics.

ISBN 87-7882-187-8 (print); ISBN 87-7882-188-6 (online).

WP 06-11 Sebastian Buhai and Marco van der Leij: A Social Network Analysis of Occupational Segregation.

ISBN 87-7882-189-4 (print); ISBN 87-7882-190-8 (online).

2007:

WP 07-1 Christina Bjerg, Christian Bjørnskov and Anne Holm: Growth, Debt Burdens and Alleviating Effects of Foreign Aid in Least Developed Countries.

ISBN 87-7882-191-6 (print); ISBN 87-7882-192-4 (online).

WP 07-2 Jeremy T. Fox and Valérie Smeets: Do Input Quality and Structural Productivity Estimates Drive Measured Differences in Firm Productivity?

ISBN 87-7882-193-2 (print); ISBN 87-7882-194-0 (online).

WP 07-3 Elisabetta Trevisan: Job Security and New Restrictive Permanent Contracts. Are Spanish Workers More Worried of Losing Their Job?

ISBN 87-7882-195-9 (print); ISBN 87-7882-196-7 (online).

WP 07-4 Tor Eriksson and Jaime Ortega: Performance Pay and the "Time Squeeze”.

ISBN 9788778822079 (print); ISBN 9788778822086 (online). 
WP 07-5 Johan Moritz Kuhn: My Pay is Too Bad (I Quit). Your Pay is Too Good (You're Fired).

ISBN 9788778822093 (print); ISBN 9788778822109 (online).

WP 07-6 Christian Bjørnskov: Social trust and the growth of schooling. ISBN 9788778822116 (print); ISBN 9788778822123 (online). 